\title{
Fish and mussels: Importance of fish for freshwater mussel conservation
}

\author{
Vanessa Modesto $^{1,2}$ (D) | Martina llarri ${ }^{2}$ (D) | Allan TSouza ${ }^{3}$ (D) | Manuel Lopes-Lima ${ }^{2,4}$ (i) | \\ Karel Douda ${ }^{5}$ (D) | Miguel Clavero ${ }^{6}$ | Ronaldo Sousa ${ }^{1,2}$ (D)
}

${ }^{1} \mathrm{CBMA}$ - Centre of Molecular and Environmental Biology, Department of Biology, University of Minho, Braga, Portugal

${ }^{2}$ Interdisciplinary Centre of Marine and Environmental Research (CIIMAR/ CIMAR), Terminal de Cruzeiros do Porto de Leixões, Matosinhos, Portugal

${ }^{3}$ Institute of Hydrobiology, Biology Centre of the Czech Academy of Sciences, České Budějovice, Czech Republic

${ }^{4} \mathrm{CIBIO}$ Research Centre in Biodiversity and Genetic Resources, InBIO, Vairão, Vila do Conde, Portugal

${ }^{5}$ Department of Zoology and Fisheries, Czech University of Life Sciences Prague, Prague, Czech Republic

${ }^{6}$ Estación Biológica de Doñana-CSIC, Sevilla, Spain

\section{Correspondence}

Vanessa Modesto, CBMA - Centre of Molecular and Environmental Biology, Department of Biology, University of Minho, Braga, Portugal.

Email: vane.modesto@gmail.com

\section{Funding information}

Fundação para a Ciência e a Tecnologia, Grant/Award Number: SFRH/ BD/108298/2015, SFRH/BPD/90088/2012, SFRH/BD/115728/2016, PTDC/ AGRFOR/1627/2014; Grantová Agentura České Republiky, Grant/Award Number: 1305872S

\begin{abstract}
Co-extinctions are increasingly recognized as one of the major processes leading to the global biodiversity crisis, but there is still limited scientific evidence on the magnitude of potential impacts and causal mechanisms responsible for the decline of affiliate (dependent) species. Freshwater mussels (Bivalvia, Unionida), one of the most threatened faunal groups on Earth, need to pass through a parasitic larval (glochidia) phase using fishes as hosts to complete their life cycle. Here, we provide a synthesis of published evidence on the fish-mussel relationship to explore possible patterns in co-extinction risk and discuss the main threats affecting this interaction. We retrieved 205 publications until December 2015, most of which were performed in North America, completed under laboratory conditions and were aimed at characterizing the life cycle and/or determining the suitable fish hosts for freshwater mussels. Mussel species were reported to infest between one and 53 fish species, with some fish families (e.g., Cyprinidae and Percidae) being used more often as hosts than others. No relationship was found between the breadth of host use and the extinction risk of freshwater mussels. Very few studies focused on threats affecting the fish-mussel relationship, a knowledge gap that may impair the application of future conservation measures. Here, we identify a variety of threats that may negatively affect fish species, document and discuss the concomitant impacts on freshwater mussels, and suggest directions for future studies.
\end{abstract}

\section{KEYWORDS}

co-extinctions, fish, freshwater mussels, hosts, secondary extinctions, Unionida

\section{$1 \mid$ INTRODUCTION}

Freshwater ecosystems host a disproportionally high biodiversity in relation to their size and provide relevant ecosystem services (Dudgeon et al., 2006), but they are highly impacted by several human activities (Allan \& Flecker, 1993; Dudgeon et al., 2006). As a result, freshwater ecosystems are among the most threatened worldwide, hosting high proportions of imperilled organisms and concentrating an increasing number of species extinctions (Brook, Sodhi,
\& Bradshaw, 2008; Jenkins, 2003; Ricciardi, Neves, \& Rasmussen, 1998).

The extinction or the massive decline of a species can lead to secondary extinctions due to the loss of obligate interactions in specialized relationships (Brodie et al., 2014). Co-extinction is the simplest type of secondary extinction and occurs when the loss of one taxon leads to the loss of another (Brodie et al., 2014; Dunn, Harris, Colwell, Koh, \& Sodhi, 2009). In spite of this theoretical simplicity, co-extinction is still a poorly understood component of the global biodiversity crisis (Koh 
et al., 2004). The specificity of biotic interactions is a crucial factor driving co-extinctions (Moir et al., 2010), which should be especially severe in obligate mutualistic or parasitic interactions (Dunn et al., 2009; Koh et al., 2004).

With 840 described species worldwide (Graf \& Cummings, 2007), freshwater mussels (Bivalvia, Unionida) form a diverse faunal group. They play key ecological roles in river and lake ecosystems, including nutrient cycling, water filtration or providing biogenic habitat for other organisms (Atkinson, Kelly, \& Vaughn, 2014; Spooner, Vaughn, \& Galbraith, 2012; Strayer et al., 2004; Vaughn, 2018; Vaughn \& Hakenkamp, 2001; Vaughn, Nichols, \& Spooner, 2008). At the same time, freshwater mussels are among the most threatened faunal groups globally (Lopes-Lima et al., 2014). The drivers of the decline of freshwater mussels include habitat loss, fragmentation and degradation, over-exploitation, climate change, and the introduction of non-native species (Lopes-Lima et al., 2017; Strayer et al., 2004). Additionally, the poor conservation status of this group is also linked to the trends of freshwater fish species (Haag, 2012; Strayer, 2008). The life cycle of freshwater mussels includes a parasitic stage, in which the larvae known as glochidium or lasidium (plural glochidia or lasidia, respectively) need to attach to fish (rarely to amphibians) to continue its development (Kat, 1984; Strayer, 2008; Watters, 1994). This parasitic stage distinguishes freshwater mussels from all other bivalves (Haag, 2012). For simplicity, hereafter we will use only the term glochidia, which is by far the most frequent larval type among freshwater mussels. Interestingly, some fish groups (such as bitterlings, Acheilognathinae) can even directly parasitize freshwater mussels by laying their eggs into the gills of a mussel, potentially affecting their fitness and population dynamics (for a review, see Smith, Reichard, Jurajda, \& Przybylski, 2004).

The dynamic interactions between the freshwater mussel and their fish host are crucial for mussel populations (but see Lellis \& King, 1998 and Dickinson \& Sietman, 2008), mainly due to the reduced lifespan of glochidia and their limited dispersal capacity (Bauer, 2001; Haag, 2012). But these interactions may also contribute to the unfavourable conservation status of freshwater mussels, because complex life histories are especially sensitive to changing environmental conditions (Koh et al., 2004). Therefore, understanding the fish-mussel relationship is critical for the conservation of freshwater mussels. In this context, this study aimed to (i) summarize the published evidence on the relationships between fish and freshwater mussels, (ii) assess the conservation implications of the fish-mussel relationship, (iii) discuss the main drivers of the decline of fish that may be responsible for secondary declines of freshwater mussels and (iv) address future directions for conservation-aimed research on fish-mussel relationships.

\section{2 | WHY ARE FISH IMPORTANT FOR FRESHWATER MUSSELS?}

The life of freshwater mussels is initiated when the eggs are deposited in the interlamellar spaces (water tubes) of the gills of females, where they are fertilized by sperm filtered from the water column (Haag,
2012; Figure 1). After fertilization, the larvae develop into glochidia and are released by the parent mussel (Figure 1 ) ranging from approximately 2-6 weeks (short-term brooders) to up to 8 months (long-term brooders) (Haag, 2013). Annual fecundity in freshwater mussel species ranges from $<2,000$ to $>10,000,000$ glochidia (Bauer, 1987a; Haag, 2013). However, glochidia of most species have very low survival rates (up to $99.99 \%$ of glochidia fail to attach to a suitable host; Haag, 2012; Jansen, Bauer, \& Meike, 2001; Strayer, 2008; Young \& Williams, 1984). Glochidial release comprises both passive (i.e., simple release in the water column) and active (i.e., including modifications for fish attraction) strategies (see Barnhart, Haag, \& Roston, 2008; Haag, 2012; Strayer, 2008). Active strategies include rhythmic contractions of mantle lures, broadcast masses of glochidia involved in mucus strands or freely discharged, release of glochidia packages in conglutinates that resemble food items, holding conglutinates in the water tubes allowing for a fast discharge in response to the fish host proximity/activity and development of a lure to capture the fish host between the valves for glochidia release during entrapment (reviewed in Barnhart et al., 2008). Although a great variety of strategies for host attraction and successful infestation have already been described, many more possibly occur, because most of these strategies were mainly reported for North American species.

Released glochidia can survive in the water column between a few hours and 14 days, varying among species and in relation to abiotic conditions (Bauer, 1994; Haag, 2012; Jansen et al., 2001). Drifting glochidia are able to grab and attach to all kinds of surfaces, including many living organisms (Haag, 2013). If attached to a suitable fish host, glochidia will encyst (Fisher \& Dimock, 2002; Nezlin, Cunjak, Zotin, \& Ziuganov, 1993), a process that takes place mainly in the gills (hookless glochidia) and fins (hooked glochidia). Glochidia may remain encysted from only a few hours to several weeks, a variability related to the identity of the freshwater mussel and the fish host, the attachment position and the abiotic conditions, especially water temperature (see examples in Bauer, 1994; Dillon, 2000; Roberts \& Barnhart, 1999; Taeubert, El-Nobi, \& Geist, 2014).

The relationship between glochidia and fish is mainly described as phoretic (i.e., a form of symbiosis where the symbiont is mechanically transported by its host) rather than nutritive or for protection. Glochidia usually do not grow while on the hosts (but see Barnhart et al., 2008; Douda, 2015; Fritts, Fritts, Carleton, \& Bringolf, 2013; Reis, CollaresPereira, \& Araujo, 2014; Taeubert et al., 2014), and they have a small (although detectable) impact on fish fitness and behaviour, which may increase at high levels of infestation and when mussels have longer encystment periods (as those of margaritiferid and quadruline species) (Horký, Douda, Maciak, Závorka, \& Slavík, 2014; Slavík et al., 2017; Thomas, Adamo, \& Moore, 2005). The main advantage of having fish as hosts is thought to be related to dispersal, including upstream colonization (Barnhart et al., 2008; Horký et al., 2014; Schwalb, Morris, \& Cottenie, 2015; Schwalb, Poos, \& Ackerman, 2011; Terui et al., 2014) and promoting connectivity among populations (Leibold et al., 2004; Newton, Woolnough, \& Strayer, 2008).

Many glochidia cannot complete their metamorphosis, being prematurely sloughed off from fish as a result of physiological and 


\section{Mussel life cycle}

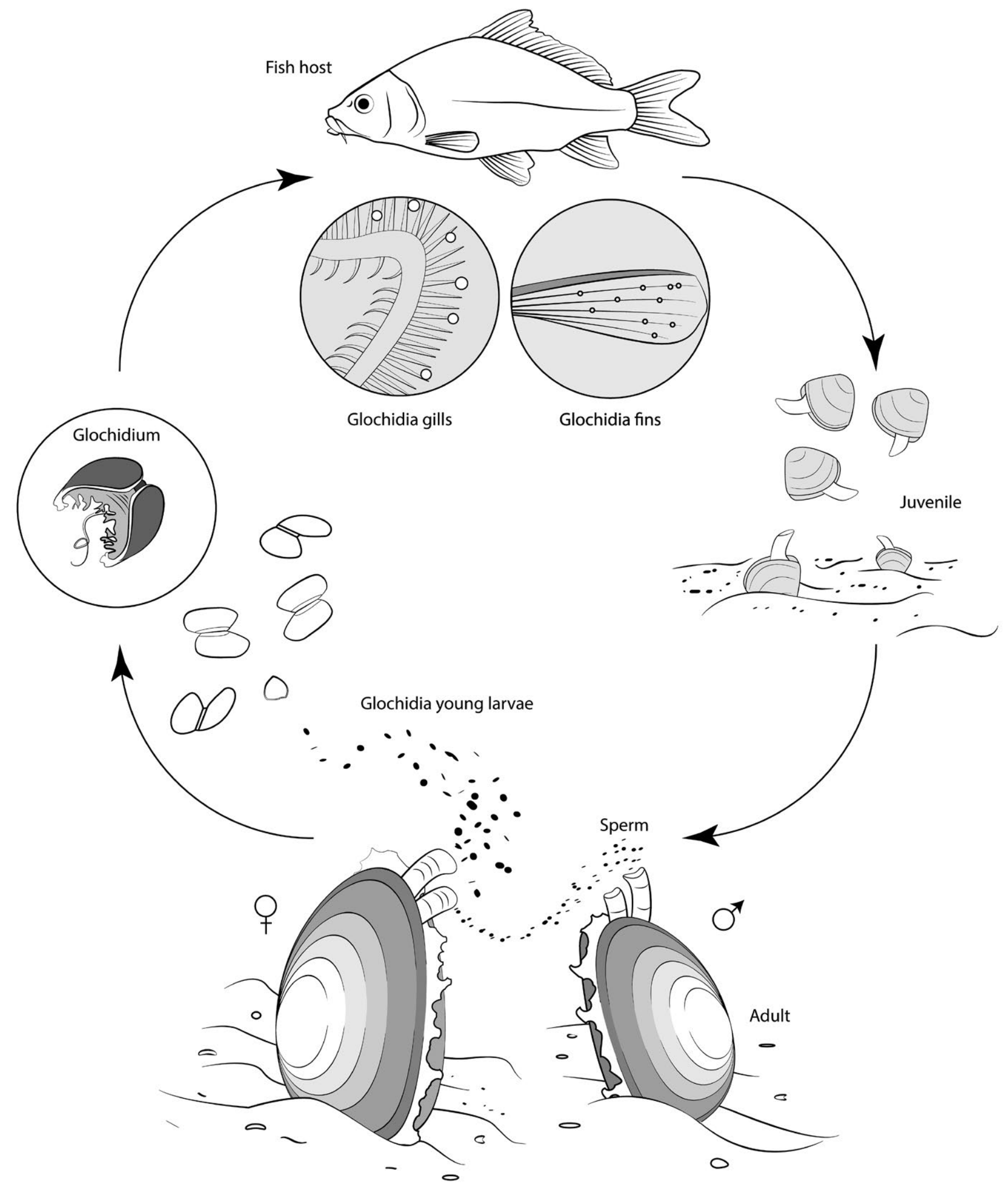

FIGURE 1 General scheme of the freshwater mussels' life cycle 
immunological incompatibility or by mechanical means. Host quality may also vary with fish age (Bauer, 1987a,b). The chance of a successful encystment is smaller in fish that have been previously infected with glochidia, due to adaptive immune response (Bauer, 1987a; Dodd, Barnhart, Rogers-Lowery, Fobian, \& Dimock, 2006). Initiation of the adaptive immune response is a natural process but can be problematic if caused by an invasive mussel species such as Chinese pond mussel (Sinanodonta woodiana, Unionidae) (Donrovich et al., 2017). Young fish hosts are generally the most infested, because they are usually numerous and lack a well-developed immune response. In addition, younger fish tend to use shallow waters near the banks, which is often the preferred habitat of most freshwater mussel species (Santos et al., 2015; Sousa et al., 2016; Varandas et al., 2013). However, older fish that have not been previously infested may produce a high number of viable juveniles (due to their larger body) and may increase dispersal distances (Bauer, 1987b; Blažek \& Gelnar, 2006; Young \& Williams, 1984).

Mussel species that associate with only one or a few fish species (the so-called host specialist species) probably have higher risks of losing suitable hosts in a changing fish community. While the same is less probable for glochidia that are able to parasitize nearly any fish (the so-called host generalist species), including non-native species (Douda et al., 2013; Haag, 2012; Kneeland \& Rhymer, 2008; Watters \& O'Dee, 1998). Fish host species are generally classified as primary or marginal hosts considering the higher or lower transformation rates of glochidia into juveniles (Haag \& Warren, 2003). However, this might be an oversimplification, because there is probably a more continuous transition between physiologically suitable and unsuitable hosts (Douda, Horký, \& Bíly, 2012). Host compatibility also varies at the population level (Karlsson, Larsen, \& Hindar, 2013; Taeubert, Denic, Gum, Lange, \& Geist, 2010), a specificity that might lead to co-extirpations of particular freshwater mussel populations (Douda et al., 2014; Österling \& Larsen, 2013; Rogers, Watson, \& Neves, 2001; Serb \& Barnhart, 2008). This last topic has been almost ignored in earlier studies but warrants further attention.

\section{3 | CONSERVATION IMPLICATIONS OF THE FISH-MUSSEL RELATIONSHIP}

To assess the importance of the fish-mussel relationship, we performed a literature review using the database developed by LopesLima et al. (2014) and searching for published studies related to freshwater mussel reproduction and identification of possible hosts. This database was updated searching for published studies until 31 December 2015 available in ISI Web of Knowledge, in the newsletters from the Freshwater Mollusk Conservation Society (Ellipsaria and Triannual Unionid Report) and in the Freshwater Mollusk Bibliography Database (http://ellipse.inhs.uiuc.edu:591/mollusk/biblio.html). For each publication in the database, we extracted the following information: (i) year of publication (1910-2015); (ii) continent (Africa, Asia, Europe, North America-including Mexico, Oceania and South America-including Central American countries); (iii) study theme (life cycle, fish hosts, physiology, conservation and threats); (iv) freshwater mussel species; ( $v$ ) number of fish host species; (vi) status of the freshwater mussel species in the study area (native or non-native); (vii) conservation status of the freshwater mussel species as reported by the International Union for Conservation of Nature (IUCN) Red List (i.e., not evaluated-NE, data deficient-DD, least concern-LC, near threatened-NT, vulnerable-VU, endangered-EN, critically endangered-CR, or extinct-EX); (viii) identity of fish host species; (ix) status of the fish host species in the study area (native or non-native); (x) conservation status of the fish host species (IUCN Red List categories as described above); (xi) fish host presence or absence in the freshwater mussel natural environment; (xii) fish host habitat use, defined as demersal (species living on or near the bottom and feeding on benthic organisms), benthopelagic (species living and feeding near the bottom, in mid-waters or near the surface while feeding on benthic as well as free swimming organisms), pelagic (fish species not associated with the bottom of water bodies), after Fishbase (2015); (xiii) infestation process (i.e., if the study was under natural (infested fish caught in the wild) or laboratory conditions (artificial infestation of fish in the laboratory), or a combination of both); and (xiv) whether the aim was to monitor the successful encystment of the glochidia or the successful metamorphosis from glochidia to juvenile stages.

To investigate the possible co-extinction risk patterns, we crossed the information on freshwater mussels and their fish hosts and used a one-way PERMANOVA (type-III; seven levels: IUCN categories except EX, as a fixed factor, and based on a Euclidean resemblance matrix; the homogeneity of variance was also tested through PERMDISP) to test whether there is a relationship between the number of fish hosts and the IUCN conservation status of freshwater mussels. We also assessed possible associations between the subfamilies of freshwater mussels and the families of fish hosts and between the subfamilies of freshwater mussels and the fish host habitat to assess possible non-random preferences using Chord Diagrams from the "circlize" package in R v.3.0.2 (Gu, Gu, Ellis, Schlesner, \& Brors, 2014; R Development Core Team, 2014). Finally, to evaluate the geographic patterns of extinction risk and coverage of extinction risk assessments, we grouped data on the conservation status from the IUCN Red List at the continental level. The number of non-evaluated species was determined by comparing total species of fish and freshwater mussels per continent, from Lévêque, Oberdoff, Paugy, Stiassny, and Tedesco (2008) and Graf and Cummings (2016), respectively, and the number of species assessed by IUCN.

Our database includes a total of 205 publications (Table S1) that clearly identified hosts of freshwater mussels. The number of publications tended to increase over time but, after peaking in the 19962000 period ( 43 publications), it decreased and stabilized at around 30 publications per 5-year periods (Figure 2).

Most of the studies (79\%) were performed in North America, followed by Europe (14\%), Asia (4\%) and the other continents (3\%). One of the reasons for the highest scientific production in North America may be related to the high number of freshwater mussel species in this geographic area. Around one-third (31\%) of the North American freshwater mussels is threatened (Figure 3), and both richness and imperilment may increase the interest in studying mussels in this continent. 

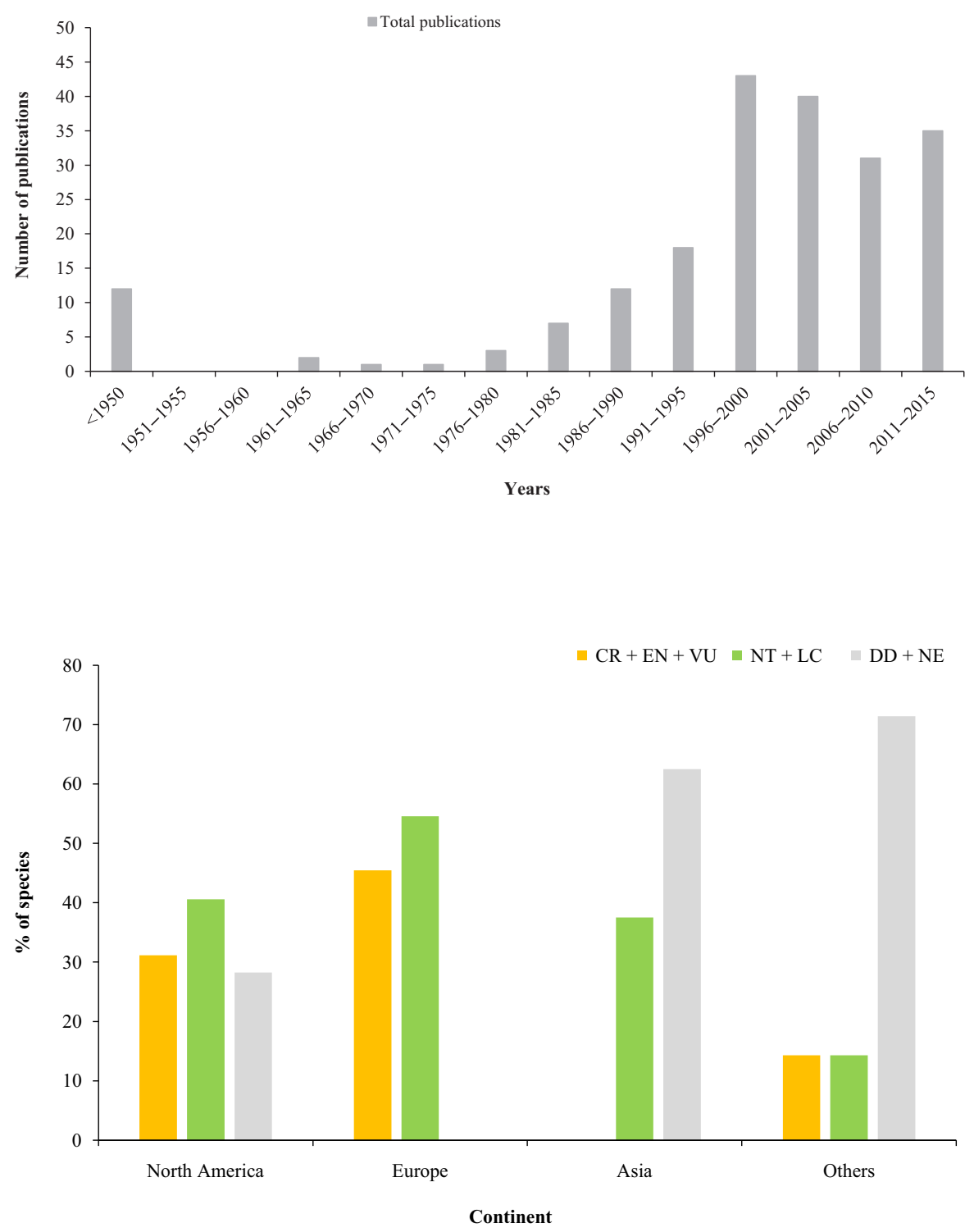

FIGURE 2 Number of publications that focused on the fish-mussel relationship along the years $(n=205)$
FIGURE 3 Percentage of freshwater mussels' species by IUCN categories in each continent $\left(n_{\text {North America }}=138\right.$; $n_{\text {Europe }}=11 ; n_{\text {Asia }}=8 ; n_{\text {Others }}=7$ ) which were reported on the publications that focused on the fish-mussel relationship $(n=205)$. Three categories based on IUCN were used per continent: $\mathrm{CR}+\mathrm{EN}+\mathrm{VU}$ (critically endangered-CR, endangered-EN, vulnerable-VU), NT+LC (near threatened-NT, least concern-LC) and DD+NE (data deficient-DD, not evaluated-NE) [Colour figure can be viewed at wileyonlinelibrary.com]
Asia also has a high number of species and some of them are also threatened (Zieritz et al., 2018; but see Figure 3), but the number of studies in this continent is low. Therefore, reasons such as scientific productivity, research and/or conservation funding, or our failure to identify publications written in Russian, Chinese, Japanese, Thai, etc., may be associated with the scarcity of Asian studies in our review. Similar geographic biases in published studies have been reported for many other groups of organisms, including fishes (Closs, Krkosek, \& Olden, 2016). In Europe, the somewhat low number of publications may relate to species-poor mussel fauna of the continent, but also to the lower number of mussel researchers when compared to North America (Lopes-Lima et al., 2017).

The majority of studies focused on fish host identification (50\%) or on the general description of the freshwater mussel life cycle (36\%). Few studies dealt with physiology (8\%) or conservation (6\%). This low number of conservation-related studies was somehow surprising because the host identification and the documentation of main threats affecting the host-affiliate interactions are crucial steps necessary to the conservation of freshwater mussels (Douda, K., Horký, P., \& Bílý, M. 2012; Haag \& Stoeckel, 2015; Strayer, 2008).

Most of the studies were performed in laboratory ( $91 \%$ of studies), with $5 \%$ performed in the field and $4 \%$ in both laboratory and field conditions. In studies that combined information from the laboratory and the field, glochidia encystment was quantified on wild fish, while juvenile recruitment and further growth were performed in the laboratory. Interestingly, some freshwater mussel species were able to infest certain fish species in laboratory even if those particular species did not occur in sympatry ( $4 \%$ of studies). Nearly $86 \%$ of the studies focused on the whole process of glochidia development (from the infestation to juvenile stage), whereas $14 \%$ investigated the suitability of fish hosts by the identification of successful glochidia encystment.

Published studies dealt with a total of 164 freshwater mussel species (Table S2). Only Chinese pond mussel was studied both in its native (Asia) and in its non-native (Europe and Central America) ranges. The number of suitable fish hosts ranged between one (Margaritifera laevis, Margaritiferidae) and 53 (Strophitus undulatus, Unionidae) (Figure 4). 


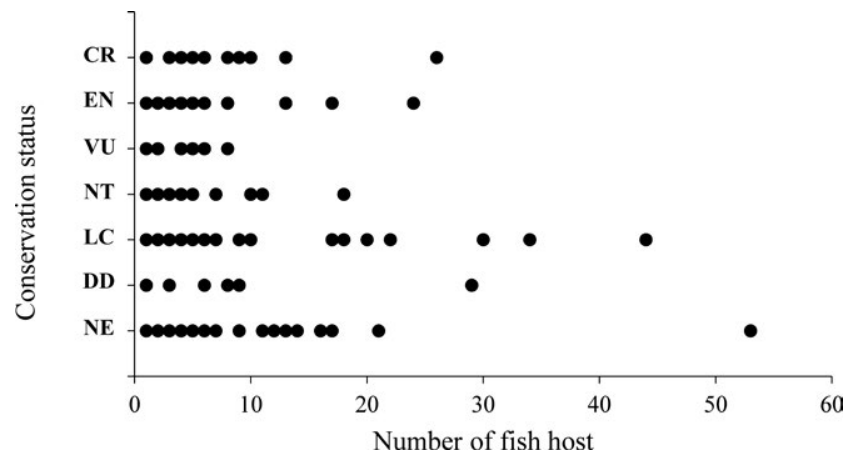

FIGURE 4 Relationship between the number of fish hosts and the IUCN categories of freshwater mussels ( $n=164$ ) (adapted from Strayer, 2008)

Although we had hypothesized that host specialist mussel species would be more vulnerable to human impacts, no significant differences were observed in the comparison of the number of fish hosts per freshwater mussel IUCN Red List categories (pseudo- $F=1.14 ; p>.05$; Figure 4).

A total of 332 species were considered suitable hosts for the mussels: 326 fish, four amphibians and two insects (see Table S3 for list of fish hosts). Most freshwater mussel species (94\%) infested exclusively native fish, but a few host generalist species (e.g., Popenaias popeii, Unionidae; paper pondshell [Utterbackia imbecillis, Unionidae], carter's freshwater mussel [Westralunio carteri, Hyriidae]) were also able to parasitize non-native fish. Patterns of fish host use were non-random, with species from the Cyprinidae and Percidae families functioning more frequently as hosts than other families (Figure 5a). In some circumstances, these patterns are understandable because some of these fish families have a high number of species (i.e., Cyprinidae) and are closely associated with the benthos; therefore, they have higher chances to be infested by freshwater mussels (Strayer, 2008). Indeed, most of the mussels' subfamilies infested mainly demersal and benthopelagic fish species (Figure $5 b$ ). The same non-random pattern was observed for mussels' subfamilies like Anodontinae, Ambleminae and to a lesser extent Unioninae, which used a higher number of fish family hosts than the other mussel taxa (Figure 5a). However, a close association of the freshwater mussel family Margaritiferidae with the Salmonidae and an exclusive pattern between the Iridinidae mussels with the fish family Cichlidae was also observed (Figure 5a). In fact, some of the fish families in the Southern Hemisphere present a high level of threatened species such as the cichlids and galaxiids enhancing the urgency in understanding their roles as hosts.

Eight per cent (27 of 326) of the fish host species retrieved in this review are either threatened (CR, EN or VU) or near threatened (NT), a proportion that rose to $41 \%$ (67 of 164) for freshwater mussels. The Margaritiferidae family is the most representative example of this high level of imperilment. Interestingly, the Margaritiferidae hosts comprised species from the Acipenseridae and Salmonidae, which are also highly threatened (Figure 6a,b). However, no relationship was found between the conservation status of other mussel families or subfamilies and that of their fish hosts.

Finally, the inclusion of freshwater fish and mussel species in the IUCN Red List is quite uneven across taxa and geographic regions
(Figure 7), as has been already described for other faunal groups (Darwall et al., 2011). The Southern Hemisphere is clearly under evaluated, especially South America, where only a small proportion of freshwater mussel and fish species have already been assessed. In contrast, Europe is the continent where the ratio of evaluated species is higher. The ratio for North America is somehow lower than expected, probably because only few Mexican freshwater mussel and fish species have been assessed by the IUCN. For both taxonomic groups, almost half of the assessed species are near threatened or threatened with extinction globally. However, if we look to the continents where available information is higher (i.e., Europe and North America), the number of threatened species increases to $76 \%$. This is probably due to the fact that the criteria used in IUCN assessments require high-quality data on species distributions and/or population trends, which are more widely available in these two continents.

\section{4 | CHANGES IN THE FISH FAUNA AND THEIR INTERACTION WITH FRESHWATER MUSSELS}

The extensive decline of freshwater fish species is a global concern (Dudgeon et al., 2006; Jenkins, 2003). Major threats are directly linked to human activities, encompassing habitat loss, fragmentation and degradation, over-exploitation, pollution, climate change, and introduction of non-native species (Kerckhove, Minns, \& Chu, 2015; Leprieur, Beauchard, Blanchet, Oberdorff, \& Brosse, 2008; Liermann, Nilsson, Robertson, \& Ng, 2012; Xenopoulos et al., 2005). Several of these threats can have direct impacts on freshwater mussel populations (reviewed in Strayer, 2008; Haag, 2012), but the impacts can also be indirect, and mediated by declines in fish hosts.

Of the 326 fish hosts identified in our literature review, 219 (i.e., $67 \%)$ had no information on threats reported by the IUCN Red List. For the remaining 107 fish hosts, the IUCN Red List cited a total of 436 threats (mean 1.28 threats per species; range 1-5) of which habitat loss and fragmentation comprise $39 \%$, pollution $29 \%$, overexploitation $18 \%$, non-native species $11 \%$ and climate change $3 \%$ (for detailed information, see Table S3).

Although the assessments of fish-mussel host compatibility are highly incomplete, preventing detailed generalizations about trait- or taxa-related risks of freshwater mussel and fish co-extinctions, they do provide numerous examples or indications of the pervasive role of fish in mussel conservation. Below, we focus primarily on these identified threats that can affect fish host interactions and also indirectly increase the risk of extinction of freshwater mussels.

\section{1 | Habitat loss, fragmentation and degradation}

Habitat loss due to the construction of dams, river channelization, water abstraction or other direct human interventions on freshwater ecosystems has been shown to be associated with population declines of several fish species (Dudgeon et al., 2006). The fragmentation of riverine habitats by dams may block migration, an impact that 

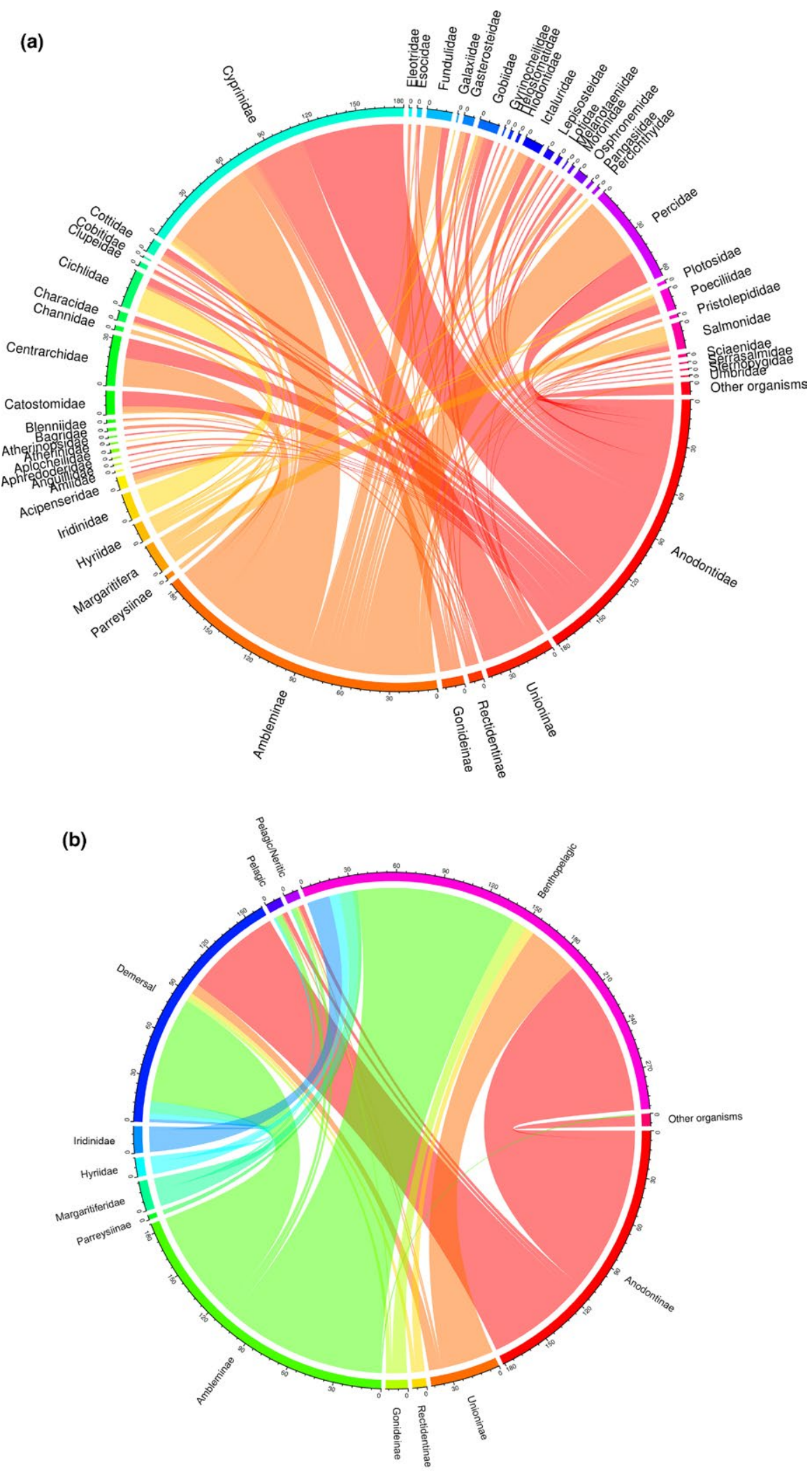

FIGURE 5 Chord diagrams with the interaction of the mussels' subfamilies (or families in the case of Hyriidae, Iridinidae and Margaritiferidae) (in upper case letters) and the fish host families (in lower case letters) used (a) and with the interaction of the fish host habitat (in lower case letters) and the mussels' subfamilies (or families in the case of Hyriidae, Iridinidae and Margaritiferidae) (in upper case letters) (b) [Colour figure can be viewed at wileyonlinelibrary.com]

is especially severe for obligate diadromous fish (Clavero \& Hermoso, 2015; Liermann et al., 2012; Limburg \& Waldman, 2009; Ruckelshaus, Levin, Johnson, \& Kareiva, 2002). The decline or extirpation of these fish species should have an impact on freshwater mussel species that depend on them (Freeman, 2003; Haag, 2012; Kelner \& Sietman, 2000). In fact, Vaughn (2012) found that local extinction rates of mussels could be predicted by their primary fish hosts and that mussels that used large migratory fish had higher extinction rates due to river 
(a)

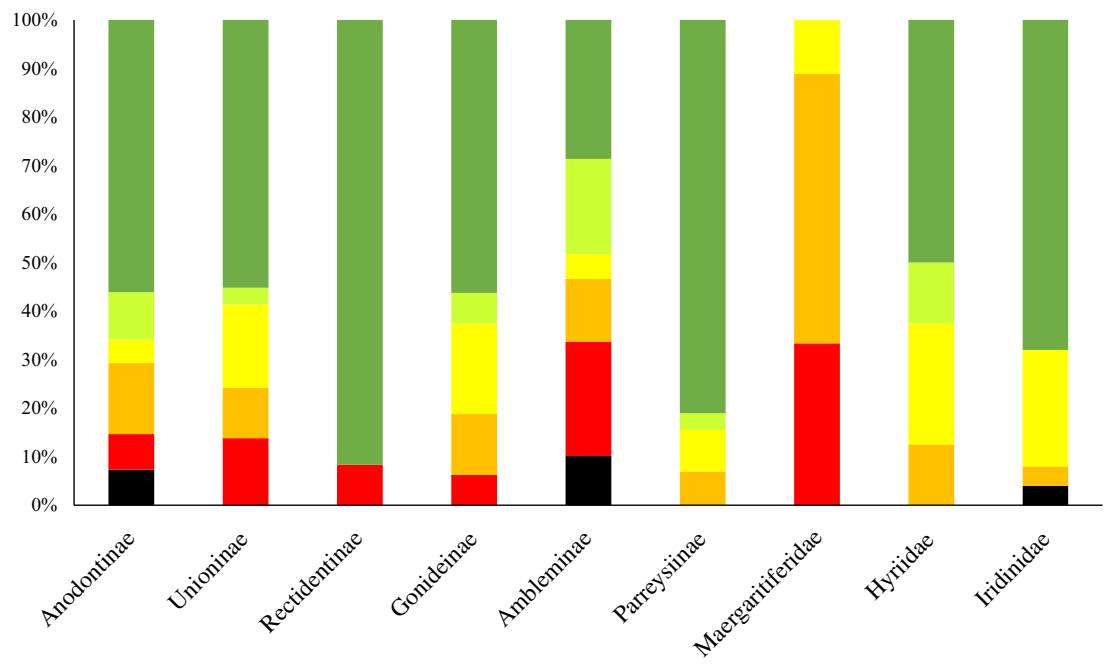

FIGURE 6 Conservation status patterns of the IUCN Red List assessments of freshwater mussels' subfamilies (or families in the case of Hyriidae, Iridinidae and Margaritiferidae) (a) and freshwater fish families (b). Species not evaluated or data deficient were not included in these analyses [Colour figure can be viewed at wileyonlinelibrary.com]

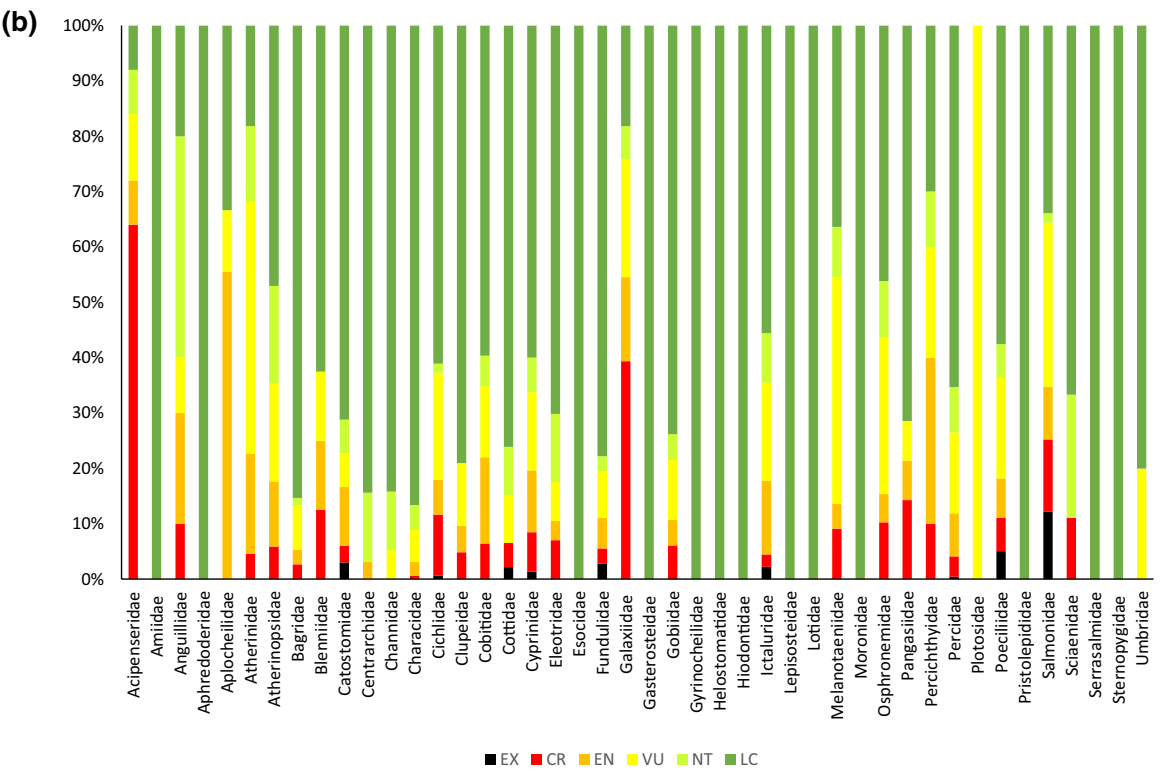

fragmentation. For example, ebonyshell (Fusconaia ebena, Unionidae) was extirpated from the upper Mississippi following a dam construction, which blocked the migration of its fish host, the skipjack shad (Alosa chrysochloris, Clupeidae) (Freeman, 2003; Theler, 1987). Cooccurring freshwater mussel species with a higher number of host relationships, such as eastern elliptio (Elliptio complanata, Unionidae) and purple bankclimber (Elliptio sloatianus, Unionidae), were less affected than F. ebena by the skipjack shad collapse (Kneeland \& Rhymer, 2008; Lellis et al., 2013).

The effects of dams are most commonly seen as an upstream blockage of fish migration, but the impediment of downstream movements and/or alterations in abiotic conditions can also be relevant. For example, reservoirs may eliminate the ecological cues used by riverine fish for downstream movements (Pelicice, Pompeu, \& Agostinho, 2015). On the other hand, reservoirs are often connected with the river downstream by a hydropower turbine system, which often produces high mortality rates (Larinier \& Travade, 2002). Furthermore, the indirect impacts of river damming on freshwater mussels that use potamodromous fish hosts can be subtler than those suffered by mussels that strictly depend on migratory fish (Brainwood, Burgin, \& Byrne, 2008), although the former remain largely unknown and deserve future attention.

The disruption of natural flow regimes through reservoir management is another widespread human impact on aquatic systems, often involving the buffering or elimination of peak floods (Poff, Olden, Merritt, \& Pepin, 2007). Floods are critical in the functioning of river ecosystems by creating and promoting spatial and temporal heterogeneity of riverine habitats and ensuring its connectivity with the river channel, features that are important for several fish and freshwater mussel species (Addy, Cooksley, \& Sime, 2012; Bunn \& Arthington, 2002; FitzHugh \& Vogel, 2011). The buffering of extreme flows due to flow management favours fish and mussel species that have preference for stable ecosystem conditions (McManamay \& Frimpong, 2015). The presence of reservoirs and flow regulation may also be responsible for changes on fish communities by promoting invasive species (Clavero, Hermoso, Aparicio, \& Godinho, 2013; Liew, Tan, \& Yeo, 


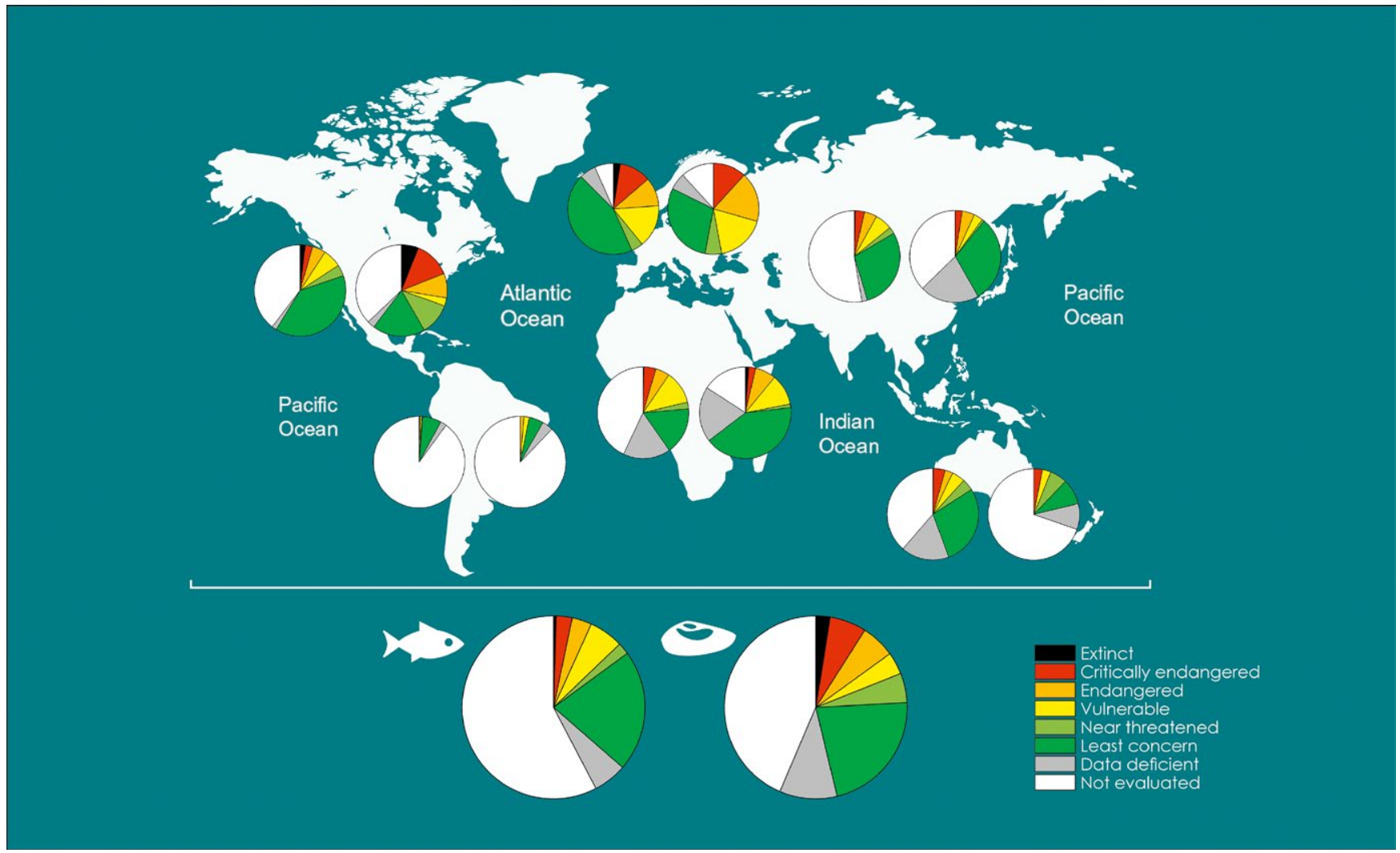

FIGURE 7 Global distribution patterns of the IUCN Red List assessments of freshwater fish (left) and freshwater mussels (right). Total number of species: Freshwater fishes (Europe = 481; Asia = 4,411; North America = 1,741; South America = 4,231; Africa = 3,240; Australia = 577; total = 14,681); Freshwater mussels (Europe = 18; Asia = 348; North America = 247; South America = 156; Africa = 82; Australia $=33 ;$ Total $=884$ ) [Colour figure can be viewed at wileyonlinelibrary.com]

2016), which can displace natives (Hermoso, Clavero, Blanco-Garrido, \& Prenda, 2011; Marchetti, Light, Moyle, \& Viers, 2004; Marchetti \& Moyle, 2001), a situation that will likely affect the fish-mussel relationship (Brainwood et al., 2008; Watters, 1996) with possible implications for mussel conservation (see below).

\subsection{Water pollution}

Pollution is known to have important effects on fish populations. Some pollutants (e.g., heavy metals) may disrupt the immune and reproductive systems of fish, whereas the nutrients from agricultural and livestock production may increase primary production and deplete dissolved oxygen, thus affecting fish through indirect pathways (Rabalais, Turner, \& Scavia, 2002; Verity, Smetacek, \& Smayda, 2002). Among freshwater organisms, mussels are one of the most sensitive groups to toxic compounds and eutrophication (Van Hassel $\&$ Farris, 2006) as has been well documented for ammonium (Strayer $\&$ Malcom, 2012) and it can be expected that water pollution would impact mussels primarily in a direct way instead of having indirect effects mediated by pollution-driven changes in fish populations. However, detailed information about environmental pollution disrupting the fish-mussel relationship is usually lacking. Water pollution could have negative impacts on fish behaviour that could affect their role as hosts. For instance, discharges of sediments, nutrients or other pollutants during the freshwater mussels' reproductive season could lead fish hosts to move to less impacted areas, thus preventing glochidia encystment. Artificially increased sediment load can indirectly disrupt the fish-mussel relationship by reducing the visibility of mantle lures due to increased turbidity or reduced adhesion of glochidia to solid structures associated with the coating of sediment (Brim Box \& Mossa, 1999; Österling, Arvidsson, \& Greenberg, 2010). Therefore, and despite the scarcity of evidence in scientific literature, it is reasonable to speculate that water pollution may affect the fishmussel relationship through the reduced density or displacement of fish hosts. Unfortunately, only limited knowledge exists on the direct susceptibility of encysted glochidia to heavy metals or increased nutrient loads to date (Cope et al., 2008; Jacobson, Neves, Cherry, \& Farris, 1997). Jacobson et al. (1997) and Rach, Brady, Schreier, and Aloisi (2006) hypothesized that the cyst provides a measure of protection from waterborne toxicants, given that they can work as a barrier isolating the encysted glochidia from the direct exposure to the pollutants. However, because glochidia of some species may feed on host tissue entrapped between the glochidia (Watters, 2007), the exposure to pollutants accumulated in fish host tissues and blood can possibly represent a potential route of contamination depending on how long and where glochidia are encysted (Cope et al., 2008). 


\section{3 | Over-exploitation}

Over-exploitation of inland fish stocks is also a major conservation problem and has driven declines in the abundance and biomass of several species with high commercial value (Allan et al., 2005; Hilborn et al., 2003; Simić, Simić, Stojković Piperac, Petrović, \& Milošević, 2014). Furthermore, the incidental capture of non-target fish species (by-catch) can also affect other less economically and profitable species (Allan et al., 2005), increasing the chances to cause negative effects on fish-mussel interactions. The over-exploitation of fish stocks is a size-biased phenomenon that results in the larger species and larger individuals as priority catch (Audzijonyte, Kuparinen, Gorton, \& Fulton, 2013; Palkovacs, 2011). Several studies have already shown that the downsizing (or extirpation of larger size-classes) of fish populations may imply a reduction in biological interactions and can even involve the loss of their functionality such as the role of fish as seed dispersers (Correa et al., 2015; Costa-Pereira \& Galetti, 2015). A generalized loss of large fish hosts can impair the reproduction of freshwater mussels. Indeed, even though large fishes can be less susceptible to glochidia encystment due to immunological responses, their ability to move large distances can be a significant vehicle to large-scale dispersal with consequences in meta-population dynamics (see Minns, 1995). Large fishes also have greater reproductive potential (Koops, Hutchings, \& McIntyre, 2004) and size-biased fisheries can lead to decreased recruitments and population declines (Audzijonyte et al., 2013), which can be critical to freshwater mussel reproduction (Bauer, 1987b; Blažek \& Gelnar, 2006).

Fisheries management can also negatively impact freshwater mussel populations by actively favouring economically or recreationally important fish species over those that are preferred as hosts for the glochidia. For example, the primary hosts (bullhead (Cottus gobio, Cottidae) and minnow (Phoxinus phoxinus, Cyprinidae)) of thick shelled river mussel (Unio crassus, Unionidae) were replaced by the excessive stocking of salmonids for angling purposes in submountain streams in the Czech Republic, and this has increased the risk of freshwater mussel extirpation from these rivers (Douda, K., Horký, P., \& Bílý, M., 2012).

\subsection{Non-native fishes}

The introduction of non-native species constitutes a global ecological and conservation problem, having driven declines and extinctions of several species (Simberloff et al., 2013). Fish are among the most widely introduced aquatic organisms (Leprieur et al., 2008) and among the ones most severely affected by non-native species (Hermoso et al., 2011). Fishes are introduced via human activities such as aquaculture, recreational and commercial fisheries, biological control, and pet and ornamental animals' industry (Gozlan, 2008; Kolar \& Lodge, 2001; Padilla \& Williams, 2004). Fish introductions can be responsible for significant changes in fish communities, including species extinctions due to the introduction of predators, diseases, parasites and competitors (Castaldelli et al., 2013; Cucherousset \& Olden, 2011; Simberloff et al., 2013), which would plausibly be translated into negative effects on freshwater mussels. The most important mechanisms by which the impacts of non-native fish may result into freshwater mussel declines are the changes in fish communities leading to changes in the host-parasite relationships. Freshwater mussels can interact with novel fish partners, and some of their former co-evolutionarily interspecific relationships can be lost (Douda, K., Horký, P., \& Bílý, M. 2012; Taraschewski, 2006). This could be particularly acute for freshwater mussels with low number of hosts, when there is a decline in the abundance of their fish hosts driven by non-native fish species. In most of the cases, non-native species may not constitute a suitable host to freshwater mussels due to the lack of physiological, ecological and evolutionary adaptations (Salonen, Marjomäki, \& Taskinen, 2016; Strayer, 2008; Watters \& O'Dee, 1998). In contrast, fish introductions can be advantageous for the few freshwater mussels that parasitize a high number of hosts, because the presence of new species enhances the availability of potential hosts for the mussels (Garner, Haggerty, \& Modlin, 1999; Kelly, Paterson, Townsend, Poulin, \& Tompkins, 2009; Poulin, Paterson, Townsend, Tompkins, $\&$ Kelly, 2011). For example, Ondračková et al. (2005) described the relationship between depressed river mussel (Pseudanodonta complanata, Unionidae) and the invasive monkey goby (Neogobius fluviatilis, Gobiidae), Levine, Lang, and Berg (2012) showed that several non-native fish species were suitable hosts for Popenaias popeii, and Douda, Vrtílek, Slavík, and Reichard (2012) and Watters and O'Dee (1998) reported that almost all tested fish were suitable hosts for chinese pond mussel and paper pondshell, respectively, regardless of their native or non-native status. However, recent findings (Douda et al., 2013) demonstrated that even the freshwater mussel species considered host generalists at local scales (such as duck mussel (Anodonta anatina, Unionidae) in Europe) can be unable to develop effectively on non-native fish species. The ongoing expansion of invasive fish species coupled with the introduction of new possible invaders (Clavero, 2011; Villéger, Blanchet, Beauchard, Oberdorff, \& Brosse, 2015) will likely result in a progressive dilution of suitable host resources.

\section{5 | Climate change}

Changes in distribution, phenology, population structure and dynamics of freshwater fish have been described or predicted in response to climate change (Comte, Buisson, Daufresne, \& Grenouillet, 2013; Comte, Murienne, \& Grenouillet, 2014; Harrod, Graham, \& Mallela, 2009; Kovach et al., 2016; Nakano, Kitano, \& Maekawas, 1996; Xenopoulos et al., 2005), and they have the potential to alter fishmussel interactions. For example, increasing temperatures might negatively affect cold-water stream fishes like salmonids that are near the edge of their distribution, which may contribute to their extirpation or shift their distribution to more suitable areas at higher latitudes or altitudes (Larios-López, Tierno De Figueroa, Alonso-Gonzalez, \& Nebot Sanz, 2015). According to Almodóvar, Nicola, and Benigno (2012), warming will lead to the widespread decline of brown trout (Salmo trutta, Salmonidae) across Iberian Peninsula, an area that represents the southern limit of the species distribution. As the freshwater pearl 
mussel (Margaritifera margaritifera, Margaritiferidae) uses exclusively salmonids as fish hosts (Hastie \& Young, 2003; Howard, 1915), the plausible decline of the brown trout will impair their future survival in the Iberian Peninsula. Warming can also lead to the decoupling of biotic interactions, which may lose their ecological functionality (MillerStruttmann et al., 2015). In the case of brown trout and freshwater pearl mussels, the former can shift its range to colder waters in response to warming, but mussels are sedentary animals with reduced mobility and thus the distribution of the mussels and its obligate fish host can become decoupled.

Changes in the river flow as a result of climate change may also contribute to changes in the fish-mussel interaction (Spooner, Xenopoulos, Schneider, \& Woolnough, 2011). Low water levels could lead to an increase in the concentration of glochidia and subsequent infestation rates. However, they can also increase fish mortalities by reducing fish swimming performance, thus increasing the risk of predation and reducing their ability to feed and avoid unfavourable conditions. The same is valid for the freshwater mussels because many species colonize shallow areas near the banks and so the decrease in the river flow may be responsible for high mortalities in those sites (Santos et al., 2015; Sousa et al., 2016). Changing environmental conditions can also directly influence the success of mussel parasitic stage through the effects on fish immune system. Although knowledge regarding this topic is still very limited, it has been documented that water temperature (Roberts \& Barnhart, 1999; Taeubert et al., 2014) and stress conditions (Douda, Martin, Glidewell, \& Barnhart, 2018; Dubansky, Whitaker, \& Galvez, 2011) can significantly influence mortality of glochidia.

\section{5 | FUTURE DIRECTIONS}

Future conservation measures focused on freshwater mussels cannot disregard the role of fish species. Despite the increasing number of studies about the fish-mussel relationship in recent years, most of them come from North America illustrating a strong geographic bias that inhibits a broader understanding of the fish-mussel relationship, because specific, yet unknown mechanisms may exist in the poorly studied areas. It seems imperative to allocate more funds and implement more effective cooperation with scientists of understudied continents. Basic data such as fish-mussel compatibility, fish community composition, host species density and habitat preferences are needed in many regions to identify potential risks from host limitation and to design effective conservation measures. Furthermore, the available information is almost exclusively focused on the characterization of the life cycle or on identifying suitable fish hosts of freshwater mussel species, with limited attempt to include threats that may impair the fish-mussel relationship.

Host compatibility should be estimated with more accuracy. A shift from species-centred approach to a more detailed perspective of the freshwater mussels' host limitations should be adopted. Because of the intraspecific variation in host compatibility, population or basin-scale studies are highly needed to better understand the spatial patterns and evolutionary dynamics of fish-mussel relationships (Caldwell, Zanatta, \& Woolnough, 2016; Karlsson et al., 2013). This information is also relevant for the delimitation of freshwater mussel's conservation units (Douda et al., 2014). It has only been recently demonstrated that fish-glochidia relationships can vary both between geographically distinct lineages of species and within these lineages also contrasting histories of sympatry (Reichard et al., 2015). This illustrates the inherent difficulty in ensuring the quality of host resources for freshwater mussels at species level because population-specific attributes arising from local adaptation and fine-scale coevolutionary dynamics can play a significant role in host compatibility.

The degree of host specificity should be also studied in more detail. Some individuals of specialist populations can be genetically less host specific, being even capable of surviving in alternative hosts (Dunn et al., 2009; Joshi \& Thompson, 1995; Rausher, 1984). Therefore, some specialist mussels may have a "bet-hedging" strategy producing batches of glochidia with reduced fitness in their typical conditions (regular host) in exchange for increased fitness in stressful conditions (alternative host). From an evolutionary perspective, this can be an important advantage, and it has been already documented that female individuals within a population differ in their compatibility with different fish host species (Douda et al., 2014; Reichard et al., 2015). Some studies with other faunal groups already addressed this "bet-hedging" strategy (Jones, Patel, Levy, Storeygard, \& Balk, 2008; Smith \& Bernatchez, 2008; Woolhouse, Haydon, \& Antia, 2005; Zaffarano, McDonald, \& Linde, 2008), but our knowledge on the potential presence of bet-hedging strategy and evolution of host specificity in mussels is limited. In this regard, an important topic for future research would combine molecular studies with evolutionary responses to understand the genetic variations within populations.

Future laboratory studies can also benefit from the evaluation of juveniles' vitality (energy reserves, growth) using for example lipid content determination, which will improve our ability to detect potential risks of host limitations (Douda, 2015). Also, field studies can be done more effectively by employing molecular tools for the identification of the glochidia detected on the fish host (Gerke \& Tiedemann, 2001; Kneeland \& Rhymer, 2008; Zieritz, Gum, Kuehn, \& Geist, 2012).

Finally, the future conservation of freshwater mussels and their fish hosts may be partly dependent on the development of methods for the artificial rearing and propagation of young mussels (Freshwater Mollusk Conservation Society 2016). Indeed, several studies call attention for the urgency to implement artificial rearing programs in association with the application of management measures to restore the natural conditions in aquatic ecosystems (Araújo, Quiros, \& Ramos, 2003; Buddensiek, 1995; Lopes-Lima et al., 2017; Schmidt \& Vandré, 2010). It is essential to understand the abiotic and biotic conditions for the successful juvenile production and subsequent development and release in natural ecosystems. Only by ensuring the sufficient quality of host resources in natural habitats, can the long-term success in freshwater mussel conservation be reached. 


\section{6 | CONCLUSION}

Although knowledge on fish-mussel relationships is increasing, many gaps still persist. The impacts of the decline of potential hosts on freshwater mussel populations are still weakly documented. It is difficult to draw general conclusions about particular species groups because of the lack of data relating mussel population declines to changes in fish host community composition. However, our approach linking the available data on fish-mussel compatibility and conservation status implies some general patterns such as the important role of demersal and benthopelagic fish of the families Cyprinidae and Percidae in Northern Hemisphere or the exclusive role of cichlid fish for the mussel family Iridinidae in Africa.

Nowadays, many freshwater mussel and fish species are highly threatened, and thus, there is an urgent need to understand the basic biological and evolutionary mechanisms governing their interaction, in order to avoid extinction cascades. We believe that a stronger collaboration between fish and mussel biologists (and also conservationists and practitioners) is needed to (i) quantify and publicize knowledge on the diversity and mutual relationships of freshwater fish and mussels; (ii) critically evaluate potential threats to endangered freshwater mussel species caused by host limitation; (iii) develop new conservation approaches for freshwater mussels with more emphasis on the management of fish host resources; and (iv) implement, monitor, evaluate and publish the results of conservation programs, either positive or negative. The absence of such collaboration will slow down further advances in conservation of freshwater mussels. Conservation of freshwater mussels can also strongly benefit from the inclusion of fish hosts into the overall plans, due to the higher societal interest on fish. The relationship between freshwater mussels and fish can be seen as a symbol for the ecological connection between different freshwater faunal groups, also representing an excellent education example for conservation. In terms of conservation management, the consideration of the freshwater mussel life cycle (with all strategies, interactions and threats) by giving emphasis to the fish-mussel relationship may also reduce financial costs as the application of conservation measures will include two faunal groups instead of one.

\section{ACKNOWLEDGEMENTS}

The authors are grateful to Frances Lucy and Jeremy Smith for the careful revision of the manuscript, to Felipe Ribas for production of Figure 1 and to the editor, Carl Smith, and one anonymous referee for helpful suggestions. The Portuguese Foundation for Science and Technology-FCT through POPH/FSE funds supported VM, MI and MLL under grants (SFRH/BD/108298/2015), (SFRH/BPD/90088/2012), (SFRH/BD/115728/2016), respectively. KD acknowledges the support from the Czech Science Foundation (13-05872S). RS acknowledges the support of the strategic programme UID/BIA/04050/2013 (POCI-01-0145FEDER-007569) funded by national funds through the FCT I.P. and by the ERDF through the COMPETE2020-Programa Operacional Competitividade e Internacionalização (POCI). This study was conducted as part of the project FRESHCO: Multiple implications of invasive species on Freshwater Mussel co-extinction processes, supported by FCT (contract: PTDC/AGRFOR/1627/2014).

\section{ORCID}

Vanessa Modesto (iD http://orcid.org/0000-0001-7619-5463

Martina llarri (iD http://orcid.org/0000-0001-6780-8221

Allan T Souza (iD http://orcid.org/0000-0002-1851-681X

Manuel Lopes-Lima iD http://orcid.org/0000-0002-2761-7962

Ronaldo Sousa (iD http://orcid.org/0000-0002-5961-5515

Karel Douda iD http://orcid.org/0000-0002-7778-5147

\section{REFERENCES}

Addy, S., Cooksley, S. L., \& Sime, I. (2012). Impacts of flow regulation on freshwater pearl mussel (Margaritifera margaritifera) habitat in a Scottish montane river. Science of the Total Environment, 432, 318-328.

Allan, J. D., Abell, R., Hogan, Z., Rebenga, C., Taylor, B. W., Welcomme, R. L., \& Winemiller, K. (2005). Overfishing of inland waters. BioScience, 55, 1041-1051.

Allan, J. D., \& Flecker, A. S. (1993). Biodiversity conservation in running waters. BioScience, 43, 32-43.

Almodóvar, G. G., Nicola, D. A., \& Benigno, E. (2012). Global warming threatens the persistence of Mediterranean brown trout. Global Change Biology, 18, 1549-1560.

Araújo, R., Quiros, M., \& Ramos, M. A. (2003). Laboratory propagation and culture of juveniles of the endangered freshwater mussel Margaritifera auricularia (Spengler, 1793). Journal of Conchology, 38, 53-60.

Atkinson, C. L., Kelly, J. F., \& Vaughn, C. C. (2014). Tracing consumer-derived nitrogen in riverine food webs. Ecosystems, 17, 485-496.

Audzijonyte, A., Kuparinen, A., Gorton, R., \& Fulton, E. A. (2013). Ecological consequences of body size decline in harvested fish species: Positive feedback loops in trophic interactions amplify human impact. Biology Letters, 9, 20121103.

Barnhart, M. C., Haag, W. R., \& Roston, W. N. (2008). Adaptations to host infection and larval parasitism in Unionoida. Journal of the North American Benthological Society, 27, 370-394.

Bauer, G. (1987a). The parasitic stage of the freshwater pearl mussel (Margaritifera margaritifera L.) III. Host relationships. Archiv für Hydrobiologie, 76, 413-423.

Bauer, G. (1987b). The parasitic stage of the freshwater pearl mussel (Margaritifera margaritifera L.) II. Susceptibility of brown trout. Archiv für Hydrobiologie, 76, 403-412.

Bauer, G. (1994). The adaptive value of offspring size among freshwater mussels (Bivalvia: Unionoidea). Journal of Animal Ecology, 63, 933-944.

Bauer, G. (2001). Framework and driving forces for the evolution of naiad life histories. In G. Bauer \& K. Wachtler (Eds.), Ecology and evolution of the freshwater mussels Unionoida (pp. 223-255). Berlin, Heidelberg: Springer-Verlag.

Blažek, R., \& Gelnar, M. (2006). Temporal and spatial distribution of glochidial larval stages of European unionid mussels (Mollusca: Unionidae) on host fishes. Folia Parasitologica, 53, 98-106.

Brainwood, M., Burgin, S., \& Byrne, M. (2008). The impact of small and large impoundments on freshwater mussel distribution in the 
Hawkesbury-Nepean River, Southeastern Australia. River Research and Applications, 24, 1325-1342.

Brim Box, J., \& Mossa, J. (1999). Sediment, land use and freshwater mussels: Prospects and problems. Journal of the North American Benthological Society, 18, 99-117.

Brodie, J. F., Aslan, C. E., Rogers, H. S., Redford, K. H., Maron, J. L., Bronstein, J. L., \& Groves, C. R. (2014). Secondary extinctions of biodiversity. Trends in Ecology and Evolution, 29, 664-672.

Brook, B. W., Sodhi, N. S., \& Bradshaw, C. J. A. (2008). Synergies among extinction drivers under global change. Trends in Ecology and Evolution, 23, 453-460.

Buddensiek, V. (1995). The culture of juvenile freshwater pearl mussels Margaritifera margaritifera L. in cages: A contribution to conservation programmes and the knowledge of habitat requirements. Biological Conservation, 74, 33-40.

Bunn, S. E., \& Arthington, A. H. (2002). Basic principles and ecological consequences of altered flow regimes for aquatic biodiversity. Environmental Management, 30, 492-507.

Caldwell, M. L., Zanatta, D. T., \& Woolnough, D. A. (2016). A multi-basin approach determines variability in host fish suitability for unionids in tributaries of the Laurentian Great Lakes. Freshwater Biology, 61, 1035-1048.

Castaldelli, G., Pluchinotta, A., Milardi, M., Lanzoni, M., Giari, L., Rossi, R., \& Fano, E. A. (2013). Introduction of exotic fish species and decline of native species in the lower Po basin, north-eastern Italy. Aquatic Conservation: Marine and Freshwater Ecosystem, 23, 405-417.

Clavero, M. (2011). Assessing the risk of freshwater fish introductions into the Iberian Peninsula. Freshwater Biology, 56, 2145-2155.

Clavero, M., \& Hermoso, V. (2015). Historical data to plan the recovery of the European eel. Journal of Applied Ecology, 52, 960-968.

Clavero, M., Hermoso, V., Aparicio, E., \& Godinho, F. N. (2013). Biodiversity in heavily modified waterbodies: native and introduced fish in Iberian reservoirs. Freshwater Biology, 58, 1190-1201.

Closs, G. P., Krkosek, M., \& Olden, J. D. (2016). Conservation of freshwater fishes. Cambridge: Cambridge University Press.

Comte, L., Buisson, L., Daufresne, M., \& Grenouillet, G. (2013). Climateinduced changes in the distribution of freshwater fish: observed and predicted trends. Freshwater Biology, 58, 625-639.

Comte, L., Murienne, J., \& Grenouillet, G. (2014). Species traits and phylogenetic conservatism of climate-induced range shifts in stream fishes. Nature Communications, 5, 5023.

Cope, W. G., Bringolf, R. B., Buchwalter, D. B., Newton, T. J., Ingersoll, C. G., Wang, N., ... Hammer, E. (2008). Differential exposure, duration, and sensitivity of unionoidean bivalve life stages to environmental contaminants. Journal of the North American Benthological Society, 27, 451-462

Correa, S. B., Araujo, J. K., Penha, J. M., da Cunha, C. N., Stevenson, P. R., \& Anderson, J. T. (2015). Overfishing disrupts an ancient mutualism between frugivorous fishes and plants in Neotropical wetlands. Biological Conservation, 191, 159-167.

Costa-Pereira, R., \& Galetti, M. (2015). Frugivore downsizing and the collapse of seed dispersal by fish. Biological Conservation, 191, 839-841.

Cucherousset, J., \& Olden, J. D. (2011). Ecological impacts of nonnative freshwater fishes. Fisheries, 36, 215-230.

Darwall, W. R. T., Holland, R. A., Smith, K. G., Allen, D., Brooks, E. G., Katarya, V., ... Cuttelod, A. (2011). Implications of bias in conservation research and investment for freshwater species. Conservation Letters, 4, 474-482.

R Development Core Team. (2014). $R$ : a language and environment for statistical computing. Austria, Vienna: R Foundation for Statistical Computing.

Dickinson, B. D., \& Sietman, B. E. (2008). Recent observation of metamorphosis without parasitism in Utterbackia imbecillis. Ellipsaria, 10, 7-8.

Dillon, R. T. (2000). The ecology of freshwater molluscs. London: Cambridge University Press.

Dodd, B. J., Barnhart, M. C., Rogers-Lowery, C. L., Fobian, T. B., \& Dimock, R. V. (2006). Persistence of host response against glochidia larvae in Micropterus salmoides. Fish and Shellfish Immunology, 21, 473-484.
Donrovich, S. W., Douda, K., Plechingerová, V., Rylková, K., Horký, P., Slavík, O., ... Sousa, R. (2017). Invasive Chinese pond mussel Sinanodonta woodiana threatens native mussel reproduction by inducing crossresistance of host fish. Aquatic Conservation: Marine and Freshwater Ecosystems, 27, 1325-1333.

Douda, K. (2015). Host-dependent vitality of juvenile freshwater mussels: implications for breeding programs and host evaluation. Aquaculture, 445, 5-10.

Douda, K., Horký, P., \& Bílý, M. (2012). Host limitation of the thick-shelled river mussel: identifying the threats to declining affiliate species. Animal Conservation, 15, 536-544.

Douda, K., Lopes-Lima, M., Hinzmann, M., Machado, J., Varandas, S., Teixeira, A., \& Sousa, R. (2013). Biotic homogenization as a threat to native affiliate species: fish introductions dilute freshwater mussel's host resources. Diversity and Distributions, 19, 933-942.

Douda, K., Martin, M., Glidewell, E., \& Barnhart, C. (2018). Stress-induced variation in host susceptibility to parasitic freshwater mussel larvae. Hydrobiologia, 810, 265-272.

Douda, K., Sell, J., Kubíková-Peláková, L., Horký, P., Kaczmarczyk, A., \& Mioduchowska, M. (2014). Host compatibility as a critical factor in management unit recognition: population-level differences in musselfish relationships. Journal of Applied Ecology, 51, 1085-1095.

Douda, K., Vrtílek, M., Slavík, O., \& Reichard, M. (2012). The role of host specificity in explaining the invasion success of the freshwater mussel Anodonta woodiana in Europe. Biological Invasions, 14, 127-137.

Dubansky, B., Whitaker, B., \& Galvez, F. (2011). Influence of cortisol on the attachment and metamorphosis of larval Utterbackia imbecillis on bluegill sunfish (Lepomis macrochirus). Biological Bulletin, 220, 97-106.

Dudgeon, D., Arthington, A. H., Gessner, M. O., Kawabata, Z. I., Knowler, D. J., Lévêque, C., ... Sullivan, C. A. (2006). Freshwater biodiversity: importance, threats, status and conservation challenges. Biological Reviews, 81, 163-182.

Dunn, R. R., Harris, N. C., Colwell, R. K., Koh, L. P., \& Sodhi, N. S. (2009). The sixth mass coextinction: are most endangered species parasites and mutualists? Proceedings of the Royal Society B: Biological Sciences, 276, 3037-3045.

Fishbase. (2015). The global species database of fish species. Retrieved from http://www.fishbase.org/. Accessed April 2017.

Fisher, G. R., \& Dimock, R. V. (2002). Morphological and molecular changes during Metamorphosis in Utterbackia imbecilis (Bivalvia: unionidae). Journal of Molluscan Studies, 68, 159-164.

FitzHugh, T. W., \& Vogel, R. M. (2011). The impact of dams on flood flows in the United States. River Research and Applications, 27, 1192-1215.

Freeman, M. C. (2003). Ecosystem-level consequences of migratory faunal depletion caused by Dams. American Fisheries Society Symposium, 35, 255-266.

Freshwater Mollusk Conservation Society (2016). A national strategy for the conservation of native freshwater mollusks. Freshwater Mollusk Biology and Conservation, 19, 1-21.

Fritts, M. W., Fritts, A. K., Carleton, S. A., \& Bringolf, R. B. (2013). Shifts in stable-isotope signatures confirm parasitic relationship of freshwater mussel glochidia attached to host fish. Journal of Molluscan Studies, 79, 163-167.

Garner, J. T., Haggerty, T. M., \& Modlin, R. F. (1999). Reproductive cycle of Quadrula metanevra (Bivalvia: unionidae) in the Pickwick Dam tailwater of the Tennessee River. American Midland Naturalist, 141, 277-283.

Gerke, N., \& Tiedemann, R. (2001). A PCR-based molecular identification key to the glochidia of European freshwater mussels (Unionidae). Conservation Genetics, 2, 285-287.

Gozlan, R. E. (2008). Introduction of non-native freshwater fish: is it all bad? Fish and Fisheries, 9, 106-115.

Graf, D. L., \& Cummings, K. S. (2007). Review of the systematics and global diversity of freshwater mussel species (Bivalvia: unionoida). Journal of Molluscan Studies, 73, 291-314. 
Graf, D. L., \& Cummings, K. S. (2016) The freshwater mussels (Unionoida) of the world (and other less consequential bivalves). MUSSEL Project. Retrieved from http://mussel-project.uwsp.edu/. Accessed June 2016.

Gu, Z., Gu, L., Ellis, R., Schlesner, M., \& Brors, B. (2014). Circlize implements and enhances circular visualization in R. Bioinformatics, 30, 2811-2812.

Haag, W. R. (2012). North American freshwater mussels: natural history, ecology, and conservation. Cambridge: Cambridge University Press.

Haag, W. R. (2013). The role of fecundity and reproductive effort in defining life-history strategies of North American freshwater mussels. Biological Reviews, 88, 745-766.

Haag, W. R., \& Stoeckel, J. A. (2015). The role of host abundance in regulating populations of freshwater mussels with parasitic larvae. Oecologia, 178, 1159-1168.

Haag, W. R., \& Warren, M. L. Jr (2003). Host fishes and infection strategies of freshwater mussels in large Mobile Basin streams, USA. Journal of the North American Benthological Society, 22, 78-91.

Harrod, C., Graham, C., \& Mallela, J. (2009). Climate change and the fishes of Britain and Ireland. Journal of Fish Biology, 74, 1143-1205.

Hastie, L. C., \& Young, M. R. (2003). Timing of spawning and glochidial release in Scottish freshwater pearl mussel (Margaritifera margaritifera) populations. Freshwater Biology, 48, 2107-2117.

Hermoso, V., Clavero, M., Blanco-Garrido, F., \& Prenda, J. (2011). Invasive species and habitat degradation in Iberian streams: an analysis of their role in freshwater fish diversity loss. Ecological Applications, 21, 175-188.

Hilborn, R., Branch, T. A., Ernst, B., Magnusson, A., Minte-Vera, C. V., Scheuerell, M. D., \& Valero, J. L. (2003). State of the world's fisheries. Annual Review of Environment and Resources, 28, 359-399.

Horký, P., Douda, K., Maciak, M., Závorka, L., \& Slavík, O. (2014). Parasiteinduced alterations of host behaviour in a riverine fish: the effects of glochidia on host dispersal. Freshwater Biology, 59, 1452-1461.

Howard, A. D. (1915). Some exceptional cases of breeding among the Unionidae. Nautilus, 29, 4-11.

Jacobson, P. J., Neves, R. J., Cherry, D. S., \& Farris, J. L. (1997). Sensitivity of glochidial stages of freshwater mussels (Bivalvia: unionidae) to copper. Environmental Toxicology and Chemistry, 16, 2384-2392.

Jansen, W., Bauer, G., \& Meike, E. Z. (2001). Glochidial mortality in freshwater mussels. In G. Bauer, \& K. Wachtler (Eds.), Ecology and evolution of the freshwater mussels Unionoida (pp. 185-210). Berlin: Springer.

Jenkins, M. (2003). Prospects for biodiversity. Science, 302, 1175-1177.

Jones, K. E., Patel, N. G., Levy, M. A., Storeygard, A., \& Balk, D. (2008). Global trends in emerging infectious diseases. Nature, 451, 990-993.

Joshi, A., \& Thompson, J. N. (1995). Trade-offs and the evolution of host specialization. Evolution Ecology, 9, 82-92.

Karlsson, S., Larsen, B. M., \& Hindar, K. (2013). Host-dependent genetic variation in freshwater pearl mussel (Margaritifera margaritifera L.). Hydrobiologia, 735, 179-190.

Kat, P. W. (1984). Parasitism and the Unionacea (Bivalvia). Biological Reviews, 59, 189-207.

Kelly, D. W., Paterson, R. A., Townsend, C. R., Poulin, R., \& Tompkins, D. M. (2009). Parasite spillback: a neglected concept in invasion ecology? Ecology, 90, 2047-2056.

Kelner, D. E., \& Sietman, B. E. (2000). Relic populations of the ebony shell, Fusconaia ebena (Bivalvia: unionidae), in the upper Mississippi River drainage. Journal of Freshwater Ecology, 15, 371-377.

Kerckhove, D. T., Minns, C. K., \& Chu, C. (2015). Estimating fish exploitation and aquatic habitat loss across diffuse inland recreational fisheries. PLoS ONE, 10, e0121895.

Kneeland, S. C., \& Rhymer, J. M. (2008). Determination of fish host use by wild populations of rare freshwater mussels using a molecular identification key to identify glochidia. Journal of the North American Benthological Society, 27, 150-160.

Koh, L. P., Dunn, R. R., Sodhi, N. S., Colwell, R. K., Proctor, H. C., \& Smith, V. S. (2004). Species coextinctions and the biodiversity crisis. Science, $305,1632-1634$.
Kolar, C. S., \& Lodge, D. M. (2001). Progress in invasion biology: predicting invaders. Trends in Ecology and Evolution, 16, 199-204.

Koops, M. A., Hutchings, J. A., \& McIntyre, T. M. (2004). Testing hypotheses about fecundity, body size and maternal condition in fishes. Fish and Fisheries, 5, 120-130.

Kovach, R. P., Muhlfeld, C. C., Al-Chokhachy, R., Dunham, J. B., Letcher, B. H., \& Kershner, J. L. (2016). Impacts of climatic variation on trout: a global synthesis and path forward. Reviews in Fish Biology and Fisheries, 26, 135-151.

Larinier, M., \& Travade, F. (2002). Downstream migration: problems and facilities. Bulletin Francaise de la Peche et de la Pisciculture, 364, 181-207.

Larios-López, J. E., Tierno De Figueroa, J. M., Alonso-Gonzalez, C., \& Nebot Sanz, B. (2015). Distribution of brown trout (Salmo trutta Linnaeus, 1758) (Teleostei: salmonidae) in its southwestern most European limit: possible causes. Italian Journal of Zoology, 82, 404-415.

Leibold, M. A., Holyoak, M., Mouquet, N., Amarasekare, P., Chase, J. M., \& Hoopes, M. F. (2004). The metacommunity concept: a framework for multi-scale community ecology. Ecology letters, 7, 601-613.

Lellis, W. A., \& King, T. L. (1998). Release of metamorphosed juveniles by the green floater, Lasmigona subviridis. US Fish and Wildlife Service, 16, 23.

Lellis, W. A., White, B. S. J., Cole, J. C., Johnson, C. S., Devers, J. L., Gray, E. V. S., \& Galbraith, H. S. (2013). Newly documented host fishes for the Eastern Elliptio mussel Elliptio complanata. Journal of Fish and Wildlife Management, 4, 75-85.

Leprieur, F., Beauchard, O., Blanchet, S., Oberdorff, T., \& Brosse, S. (2008). Fish invasions in the world's river systems: when natural processes are blurred by human activities. PeerJ, 6, e28.

Lévêque, C., Oberdoff, T., Paugy, D., Stiassny, M. L. J., \& Tedesco, P. A. (2008). Global diversity of fish (Pisces) in freshwater. Hydrobiologia, $595,545-567$.

Levine, T. D., Lang, B. K., \& Berg, D. J. (2012). Physiological and ecological hosts of Popenaias popeii (Bivalvia: unionidae): laboratory studies identify more hosts than field studies. Freshwater Biology, 57, 1854-1864.

Liermann, C. R., Nilsson, C., Robertson, J., \& Ng, R. Y. (2012). Implications of dam obstruction for global freshwater fish diversity. BioScience, 62 , 539-548.

Liew, J. H., Tan, H. K., \& Yeo, D. C. J. (2016). Dammed rivers: impoundments facilitate fish invasions. Freshwater Biology, 61, 1421-1429.

Limburg, K. E., \& Waldman, J. R. (2009). Dramatic declines in North Atlantic diadromous fishes. BioScience, 59, 955-965.

Lopes-Lima, M., Sousa, R., Geist, J., Aldridge, D. C., Araujo, R., Bergengren, J., ... Douda, K. (2017) Conservation status of freshwater mussels in Europe: state of the art and future challenges. Biological Reviews, 92, 572-607.

Lopes-Lima, M., Teixeira, A., Froufe, E., Lopes, A., Varandas, S., \& Sousa, R. (2014). Biology and conservation of freshwater bivalves: past, present and future perspectives. Hydrobiologia, 735, 1-13.

Marchetti, M. P., Light, T., Moyle, P. B., \& Viers, J. H. (2004). Fish invasions in California watersheds: testing hypotheses using landscape patterns. Ecological Applications, 14, 1507-1525.

Marchetti, M. P., \& Moyle, P. B. (2001). Effects of flow regime and habitat structure on fish assemblages in a regulated California stream. Ecological Applications, 11, 530-539.

McManamay, R. A., \& Frimpong, E. A. (2015). Hydrologic filtering of fish life history strategies across the United States: implications for stream flow alteration. Ecological Applications, 25, 243-263.

Miller-Struttmann, N. E., Geib, J. C., Franklin, J. D., Kevan, P. G., Holdo, R. M., Ebert-May, D., \& Galen, C. (2015). Functional mismatch in a bumble bee pollination mutualism under climate change. Science, 349 , 1541-1544.

Minns, C. K. (1995). Allometry of home range size in lake and river fishes. Canadian Journal of Fisheries and Aquatic Sciences, 52, 1499-1508.

Moir, M. L., Vesk, P. A., Brennan, K. E. C., Keith, D. A., Hughes, L., \& McCarthy, M. A. (2010). Current constraints and future directions in estimating coextinction. Conservation Biology, 24, 682-690. 
Nakano, S., Kitano, F., \& Maekawas, K. (1996). Potential fragmentation and loss of thermal habitats for charrs in the Japanese archipelago due to climatic warming. Freshwater Biology, 36, 711-722.

Newton, T. J., Woolnough, D. A., \& Strayer, D. L. (2008). Using landscape ecology to understand and manage freshwater mussel populations. Journal of the North American Benthological Society, 27, 424-439.

Nezlin, L. P., Cunjak, R. A., Zotin, A. A., \& Ziuganov, V. V. (1993). Glochidium morphology of the freshwater pearl mussel (Margaritifera margaritifera) and glochidiosis of the Atlantic salmon (Salmo salar): a study by scanning electron microscopy. Canadian Journal of Zoology, 72, 15-21.

Ondračková, M., Dávidová, M., Pečínková, M., Blažek, R., Gelnar, M., Valová, Z., ... Jurajda, P. (2005). Metazoan parasites of Neogobius fishes in the Slovak section of the River Danube. Journal of Applied Ichthyology, 21. 345-349.

Österling, M. E., Arvidsson, B. L., \& Greenberg, L. A. (2010). Habitat degradation and the decline of the threatened mussel Margaritifera margaritifera: influence of turbidity and sedimentation on the mussel and its host. Journal of Applied Ecology, 47, 759-768.

Österling, M. E., \& Larsen, B. M. (2013). Impact of origin and condition of host fish (Salmo trutta) on parasitic larvae of Margaritifera margaritifera. Aquatic Conservation: Marine and Freshwater Ecosystems, 23, 564-570.

Padilla, D. K., \& Williams, S. L. (2004). Beyond ballast water: aquarium and ornamental trades as sources of invasive species in aquatic ecosystems. Frontiers in Ecology and the Environment, 2, 131-138.

Palkovacs, E. P. (2011). The overfishing debate: an eco-evolutionary perspective. Trends in Ecology and Evolution, 26, 616-617.

Pelicice, F. M., Pompeu, P. S., \& Agostinho, A. A. (2015). Large reservoirs as ecological barriers to downstream movements of Neotropical migratory fish. Fish and Fisheries, 16, 697-715.

Poff, N. L., Olden, J. D., Merritt, D. M., \& Pepin, D. M. (2007). Homogenization of regional river dynamics by dams and global biodiversity implications. Proceedings of the National Academy of Sciences USA, 104, 5732-5737.

Poulin, R., Paterson, R. A., Townsend, C. R., Tompkins, D. M., \& Kelly, D. W. (2011). Biological Invasions and the dynamics of endemic diseases in freshwater ecosystems. Freshwater Biology, 56, 676-688.

Rabalais, N. N., Turner, R. E., \& Scavia, D. (2002). Beyond science into policy: gulf of Mexico hypoxia and the Mississippi River. BioScience, 52, 129-142.

Rach, J. J., Brady, T., Schreier, T. M., \& Aloisi, D. (2006). Safety of fish therapeutants to glochidia of the plain pocketbook mussel during encystment on largemouth bass. North American Journal of Aquaculture, 68, 348-354.

Rausher, M. D. (1984). Trade-offs in performance on different hosts: evidence from within- and between-site variation in the beetle Deloya guttata. Evolution, 38, 582-595.

Reichard, M., Douda, K., Przybyłski, M., Popa, O. P., Karbanová, E., Matasová, K., ... Smith, C. (2015). Population-specific responses to an invasive species. Proceedings of the Royal Society B: Biological Science, 282, 1063.

Reis, J., Collares-Pereira, M. J., \& Araujo, R. (2014). Host specificity and metamorphosis of the glochidium of the freshwater mussel Unio tumidiformis (Bivalvia: unionidae). Folia Parasitologica, 61, 81-89.

Ricciardi, A., Neves, R. J., \& Rasmussen, J. (1998). Impending extinctions of North American freshwater mussels (Unionoida) following the zebra mussel (Dreissena polymorpha) invasion. Journal of Animal Ecology, 67, 613-619.

Roberts, A. D., \& Barnhart, M. C. (1999). Effects of temperature, pH, and $\mathrm{CO}_{2}$ on transformation of the glochidia of Anodonta suborbiculata on fish hosts and in vitro. Journal of the North American Benthological Society, 18, 477-487.

Rogers, S. O., Watson, B. T., \& Neves, R. J. (2001). Life history and population biology of the endangered tan riffleshell (Epioblasma florentina walkeri) (Bivalvia: unionidae). Journal of the North American Benthological Society, 20, 582-594.
Ruckelshaus, M. H., Levin, P., Johnson, J. B., \& Kareiva, P. M. (2002). The Pacific salmon wars: what science brings to the challenge of recovering species. Annual Review of Ecology and Systematics, 33, 665-706.

Salonen, J. K., Marjomäki, T. J., \& Taskinen, J. (2016). An alien fish threatens an endangered parasitic bivalve: the relationship between brook trout (Salvelinus fontinalis) and freshwater pearl mussel (Margaritifera margaritifera) in northern Europe. Aquatic Conservation: Marine and Freshwater Ecosystems, 26, 1130-1144.

Santos, R. M. B., Fernandes, L. S., Varandas, S. G. P., Pereira, M. G., Sousa, R., Teixeira, A., ... Pacheco, F. A. L. (2015). Impacts of climate change and land-use scenarios on Margaritifera margaritifera, an environmental indicator and endangered species. Science of the Total Environment, 511, 477-488.

Schmidt, C., \& Vandré, R. (2010). Ten years of experience in the rearing of young freshwater pearl mussels (Margaritifera margaritifera). Aquatic Conservation: Marine and Freshwater Ecosystems, 20, 735-747.

Schwalb, A. N., Morris, T. J., \& Cottenie, K. (2015). Dispersal abilities of riverine freshwater mussels influence metacommunity structure. Freshwater Biology, 60, 911-921.

Schwalb, A. N., Poos, M. S., \& Ackerman, J. D. (2011). Movement of log perch - The obligate host fish for endangered snuffbox mussels: implications for mussel dispersal. Aquatic Sciences, 73, 223-231.

Serb, J. M., \& Barnhart, M. C. (2008). Congruence and conflict between molecular and reproductive characters when assessing biological diversity in the western fanshell Cyprogenia aberti (Bivalvia, Unionidae). Annals of the Missouri Botanical Garden, 95, 248-261.

Simberloff, D., Martin, J. L., Genovesi, P., Maris, V., Wardle, D. A., Aronson, J., ... Pyšek, P. (2013). Impacts of biological invasions: what's what and the way forward. Trends in Ecology and Evolution, 28, 58-66.

Simić, V. M., Simić, S. B., Stojković Piperac, M., Petrović, A., \& Milošević, D. (2014). Commercial fish species of inland waters: a model for sustainability assessment and management. Science of the Total Environment, 497, 642-650.

Slavík, O., Horký, P., Douda, K., Velíšek, J., Kolářová, J., \& Lepič, P. (2017). Parasite-induced increases in the energy costs of movement of host freshwater fish. Physiology and Behavior, 171, 127-134.

Smith, T. B., \& Bernatchez, L. (2008). Evolutionary change in human-altered environments. Molecular Ecology, 17, 1-8.

Smith, C., Reichard, M., Jurajda, P., \& Przybylski, M. (2004). The reproductive ecology of the European bitterling (Rhodeus sericeus). Journal of Zoology, 262, 107-124.

Sousa, R., Varandas, S., Teixeira, A., Ghamizi, M., Froufe, E., \& Lopes-Lima, M. (2016). Pearl mussels (Margaritifera marocana) in Morocco: conservation status of the rarest bivalve in African fresh waters. Science of the Total Environment, 547, 405-412.

Spooner, D. E., Vaughn, C. C., \& Galbraith, H. S. (2012). Species traits and environmental conditions govern the relationship between biodiversity effects across trophic levels. Oecologia, 168, 533-548.

Spooner, D. E., Xenopoulos, M. A., Schneider, C., \& Woolnough, D. A. (2011). Coextirpation of host-affiliate relationships in rivers: the role of climate change, water withdrawal, and host-specificity. Global Change Biology, 17, 1720-1732.

Strayer, D. L. (2008). Freshwater mussel ecology: a multifactor approach to distribution and abundance. Berkley: University of California Press.

Strayer, D. L., Downing, J. A., Haag, W. R., King, T. L., Layzer, J. B., Newton, T. J., \& Nichols, J. S. (2004). Changing perspectives on pearly mussels, North America's most imperiled animals. BioScience, 54, 429-439.

Strayer, D. L., \& Malcom, H. M. (2012). Causes of recruitment failure in freshwater mussel populations in southeastern New York. Ecological Applications, 22, 1780-1790.

Taeubert, J. E., Denic, M., Gum, B., Lange, M., \& Geist, J. (2010). Suitability of different salmonid strains as hosts for the endangered freshwater pearl mussel (Margaritifera margaritifera L.). Aquatic Conservation: Marine and Freshwater Ecosystems, 20, 728-734. 
Taeubert, J.-E., El-Nobi, G., \& Geist, J. (2014). Effects of water temperature on the larval parasitic stage of the thick-shelled river mussel (Unio crassus). Aquatic Conservation: Marine and Freshwater Ecosystems, 24, 231-237.

Taraschewski, H. (2006). Hosts and parasites as aliens. Journal of Helminthology, 80, 99-128.

Terui, A., Miyazaki, Y., Yoshioka, A., Kaifu, K., Matsuzaki, S.-I. S., \& Washitani, I. (2014). Asymmetric dispersal structures a riverine metapopulation of the freshwater pearl mussel Margaritifera laevis. Ecology and Evolution, 4, 3004-3014.

Theler, J. L. (1987). Prehistoric freshwater mussel assemblages of the Mississippi River in southwestern Wisconsin. The Nautilus, 101, 143-150.

Thomas, F., Adamo, S., \& Moore, J. (2005). Parasitic manipulation: where are we and where should we go? Behavioural Processes, 68, 185-199.

Van Hassel, J. H., \& Farris, J. L. (2006). Freshwater bivalve ecotoxicology. In J. L. Farris, \& J. H. Van Hassel (Eds.), Freshwater bivalve ecotoxicology (pp. 1-17). Pensacola, FL: Society of Environmental Toxicology and Chemistry.

Varandas, S., Lopes-Lima, M., Teixeira, A., Hinzmann, M., Reis, J., Cortes, R., ... Sousa, R. (2013). Ecology of Southern European pearl mussels (Margaritifera margaritifera): first record of two new populations on the rivers Terva and Beça (Portugal). Aquatic Conservation: Marine and Freshwater Ecosystems, 23, 374-389.

Vaughn, C. C. (2012). Life history traits and abundance can predict local colonisation and extinction rates of freshwater mussels. Freshwater Biology, 57, 982-992.

Vaughn, C. C. (2018). Ecosystem services provided by freshwater mussels. Hydrobiologia, 810, 15-27.

Vaughn, C. C., \& Hakenkamp, C. C. (2001). The functional role of burrowing bivalves in freshwater ecosystems. Freshwater Biology, 46, 1431-1446.

Vaughn, C. C., Nichols, S. J., \& Spooner, D. E. (2008). Community foodweb ecology of freshwater mussels. Journal of the North American Benthological Society, 27, 409-423.

Verity, P. G., Smetacek, V., \& Smayda, T. J. (2002). Status, trends and the future of the marine pelagic ecosystem. Environmental Conservation, 29, 207-237.

Villéger, S., Blanchet, S., Beauchard, O., Oberdorff, T., \& Brosse, S. (2015). From current distinctiveness to future homogenization of the world's freshwater fish faunas. Diversity and Distributions, 21, 223-235.

Watters, G. T. (1994). An annotated bibliography of the reproduction and propagation of the Unionoidea (Primarily of North America). Columbus: Ohio Biological Survey, College of Biological Sciences, Ohio State University.
Watters, G. T. (1996). Small dams as barriers to freshwater mussels (Bivalvia, Unionoida) and their hosts. Biological Conservation, 75, 79-85.

Watters, G. T. (2007). A brief look at freshwater mussel (Unionacea) biology. In J. L. Farris \& J. H. Van Hassel (Eds.), Freshwater bivalve ecotoxicology (pp. 51-64). Boca Raton, FL: RC Press, SETAC Press.

Watters, G. T., \& O'Dee, S. H. (1998). Metamorphosis of freshwater mussel glochidia (Bivalvia: unionidae) on amphibians and exotic fishes. American Midland Naturalist, 139, 49-57.

Woolhouse, M. E. J., Haydon, D. T., \& Antia, R. (2005). Emerging pathogens: the epidemiology and evolution of species jumps. Trends Ecology and Evolution, 20, 238-244.

Xenopoulos, M. A., Lodge, D. M., Alcamo, J., Märker, M., Schulze, K., \& Van Vuuren, D. P. (2005). Scenarios of freshwater fish extinctions from climate change and water withdrawal. Global Change Biology, 11, 1557-1564.

Young, M., \& Williams, J. (1984). The reproductive biology of the freshwater pearl mussel Margaritifera margaritifera in Scotland. I. Field studies. Archiv fur Hydrobiologie, 99, 405-422.

Zaffarano, P. L., McDonald, B. A., \& Linde, C. C. (2008). Rapid speciation following recent host shifts in the plant pathogenic fungus Rhynchosporium. Evolution, 62, 1418-1436.

Zieritz, A., Bogan, A. E., Froufe, E., Klishko, O., Kondo, T., Kovitvadhi, U., ... Sousa, R. (2018). Diversity, biogeography and conservation of freshwater mussels (Bivalvia: unionida) in East and Southeast Asia. Hydrobiologia, 810, 29-44.

Zieritz, A., Gum, B., Kuehn, R., \& Geist, J. (2012). Identifying freshwater mussels (Unionoida). and parasitic glochidia larvae from host fish gills: a molecular key to the North and Central European species. Ecology and Evolution, 2, 740-750.

\section{SUPPORTING INFORMATION}

Additional Supporting Information may be found online in the supporting information tab for this article.

How to cite this article: Modesto V, llarri M, Souza AT, et al.

Fish and mussels: Importance of fish for freshwater mussel

conservation. Fish Fish. 2018;19:244-259.

https://doi.org/10.1111/faf.12252 